\title{
Pemasaran Digital dan Pengenalan Green Marketing di Kecamatan Punung Kabupaten Pacitan
}

\author{
Rizki Hamdani*, Berliana Swastika \\ Fakultas Bisnis dan Ekonomika, Universitas Islam Indonesia \\ *Corresponding Email: rizki.hamdani@uii.ac.id
}

\begin{abstract}
ABSTRAK
Desa Punung merupakan salah satu wilayah yang termasuk kawasan strategis di Kabupaten Pacitan karena memiliki akses jalur Provinsi dan juga jalur menuju beberapa kawasan wisata terkenal di Kabupaten Pacitan. Desa Punung memiliki berbagai Usaha Mikro Kecil Menengah (UMKM), salah satunya adalah UMKM produk makanan kering. UMKM di sekitar Desa Punung masih memiliki wawasan terbatas tentang pemasaran digital dan bagaimana cara mengemas untuk pengiriman jarak jauh. Selain itu, pemakaian sumber daya terbatas dan sulit didaur ulang seperti plastik masih tidak terkendali dan mencemari lingkungan. Tujuan dari pelaksanaan program pemberdayaan ini untuk memberikan pemahaman kepada pelaku UMKM mengenai pemasaran digital dan strategi green marketing agar dapat memaksimalkan pemasaran produk mereka dimasa pandemi covid-19. Berdasarkan permasalahan tersebut, perlu dilakukan program pemberdayaan masyarakat untuk meningkatkan ekonomi dan kesejahteraannya dengan program KKN-PPM. Metode Pengabdian untuk mencapai tujuan tersebut adalah penyuluhan dan pelatihan pemasaran bagi pelaku UMKM serta membuat video berisi materi dan informasi mengenai pemasaran UMKM. Pelaksanaan pemberdayaan masyarakat ini mendapat respon positif dari pelaku UMKM di Desa Punung sekaligus meningkatkan kapabilitas pelaku UMKM dalam memasarkan produk melalui sosial media maupun e-commerce.
\end{abstract}

Kata Kunci: Green Marketing, Pemasaran Digital, UMKM

\section{ABSTRACT}

Punung Village is one of the areas that is included in a strategic area in Pacitan Regency because it has access to provincial routes and also routes to several well-known tourist areas in Pacitan Regency. Punung Village has various Micro, Small and Medium Enterprises (MSMEs), one of which is MSMEs for dry food products. MSMEs around Punung Village still have limited insight into digital marketing and how to package for long-distance shipping. In addition, the use of limited and difficult to recycle resources such as plastic is still uncontrolled and pollutes the environment. The purpose of implementing this empowerment program is to provide understanding to MSME actors regarding digital marketing and green marketing strategies in order to maximize their product marketing during the COVID-19 pandemic. Based on these problems, it is necessary to carry out community empowerment programs to improve their economy and welfare with the KKN-PPM program. The service method to achieve these goals is marketing counseling and training for MSME actors and making videos containing material and information about MSME marketing. The implementation of community empowerment received a positive response from MSME actors in Punung Village while increasing the capability of MSME actors in marketing products through social media and e-commerce.

Keywords: Green Marketing, Digital Marketing, MSME 


\section{PENDAHULUAN}

Covid-19 menimbulkan guncangan bagi hampir seluruh negara di dunia. Virus yang menyebar begitu cepat ke berbagai belahan bumi menyebabkan hampir seluruh negara terdampak kasus terkonfirmasi Covid-19. Setelah World Health Organization (WHO) menetapkan status Covid-19 sebagai pandemi, pergerakan barang maupun manusia secara global mendadak terhenti sementara. Terhentinya arus barang dan manusia menyebabkan kekacauan di berbagai sektor dan memunculkan berbagai peristiwa yang belum pernah terjadi sebelumnya. Permasalahan yang ditimbulkan oleh adanya Covid-19 ini tidak hanya di bidang kesehatan, tetapi juga ekonomi dan keuangan.

Adanya pandemi covid-19 yang belum mereda, maka dari itu Universitas Islam Indonesia (UII) memutuskan bahwa segala kegiatan mahasiswa dilakukan secara daring untuk meminimalisir resiko penyebaran virus. Salah satu kegiatan mahasiswa yang dilakukan secara daring atau online yaitu pelaksanaan Kuliah Kerja Nyata (KKN) angkatan 63 tahun 2021. KKN merupakan bentuk kegiatan intrakurikuler wajib yang mengintegrasikan Catur Dharma UII, pembelajaran, dan dakwah dalam kehidupan bermasyarakat. Kegiatan ini bertujuan untuk mendapatkan pengetahuan dari media online terkait pembelajaran sekolah, pemberdayaan masyarakat, dan dakwah Islamiyah.

Sektor UMKM di Indonesia akhir-akhir ini berkembang pesat, namun masih ada beberapa kendala untuk memperluas pasar dan bersaing di bidang bisnis, seperti kendala dalam pendanaan (Setiawan \& Hamdani, 2017) dan kurang memaksimalkan digital marketing (Marpaung et al., 2021). Pada masa pandemi ini, penulis juga mengamati bahwa UMKM masih banyak yang memiliki keterbatasan wawasan tentang pemasaran digital dan bagaimana cara mengemas untuk pengiriman jarak jauh. Selain itu, pemakaian sumber daya terbatas dan sulit untuk didaur ulang seperti plastik masih tidak terkendali dan mencemari lingkungan. Maka dari itu penulis juga mengangkat pengenalan strategi green marketing untuk UMKM sebagai salah satu bentuk pelestarian lingkungan.

Pemasaran digital merupakan kegiatan pemasaran yang menggunaan media digital dengan menggunakan internet yang memanfaatkan media berupa website, media sosial, e-mail, database, mobile/wireless, dan televisi digital guna meningkatkan target konsumen (Chaffey \& Ellis-Chadwick, 2016). Menurut 'Aini dan Hapsari (2019), 30 UMKM yang ada di kota Bandung menunjukkan bahwa digital marketing memberikan dampak $83,5 \%$ mampu meningkatkan penjualan produk dan sisanya $13,5 \%$ disebabkan oleh faktor lain. Perkembangan di dunia bisnis sangat kompetitif bagi para pelaku UMKM, sehingga dapat memanfaatkan digitalisasi sebagai salah satu upaya pemasaran produknya agar mampu meningkatkan kapasitas usaha yang dimiliki (Marpaung et al., 2021). Selain itu, penerapan sistem informasi juga memberikan pengaruh yang signifikan terhadap performance (kinerja) suatu organisasi (Muhammad et al., 2021) dan membantu perusahaan untuk merespon lebih cepat permintaan pelanggan akan informasi dan produknya (Hamdani et al., 2021), termasuk UMKM.

Sementara itu, konsep yang meliputi semua kegiatan pemasaran yang dikembangkan untuk merangsang dan mempertahankan sikap perilaku konsumen yang ramah lingkungan disebut sebagai green marketing (Chen \& Chang, 2013). Budaya masyarakat kurang peduli kepada lingkungan, biasanya juga terjadi pada pelaku UMKM saat mereka mendirikan usaha. Contohnya, penggunaan plastik yang berlebihan dan pembuangan limbah produksi yang kurang tepat. Pengetahuan strategi green marketing pada skala UMKM masih sangat minim sehingga penting untuk dilakukan adanya edukasi.

Berdasarkan dari objek observasi yaitu UMKM makanan kering di Kecamatan Punung, Kabupaten Pacitan yang belum menggunakan strategi pemasaran terutama pemasaran secara digital sehingga produk mereka kurang dipasarkan secara maksimal. Kebijakan Pemberlakuan Pembatasan Kegiatan Masyarakat (PPKM) karena adanya pandemi covid-19 menghambat perluasan pemasaran produk dan berkurangnya wisatawan mengurangi penjualan UMKM. Masalah yang terjadi pada UMKM tersebut disebabkan karena pelaku UMKM belum mengerti bagaimana cara memasarkan produk secara digital dan juga belum memahami cara yang baik dalam mengemas produk untuk dikirim ke luar kota. 
Tujuan dari pelaksanaan program ini untuk memberikan pemahaman kepada pelaku UMKM agar dapat memaksimalkan pemasaran produk mereka dimasa pandemi. Mereka dapat memasarkan produk melalui sosial media maupun e-commerce sehingga penjualan tidak begitu terdampak karena adanya PPKM yang berlaku. Mereka juga dapat belajar untuk mengemas produk secara aman untuk pengiriman luar kota. Di sisi lain, program pemberdayaan ini juga mengenalkan strategi green marketing untuk meningkatkan kesadaran masyarakat khususnya pelaku UMKM untuk menjaga lingkungan. Pelaku UMKM dapat menerapkan konsep ini dalam proses produksi dan pemasaran produk mereka sebagai bentuk kelestarian lingkungan. Maka dari itu, pembuatan video mengenai pemasaran UMKM dan pengenalan strategi green marketing diharapkan dapat membantu pelaku UMKM untuk lebih memasarkan produknya.

\section{METODE}

Dalam Pengabdian ini, sebagai Mitra adalah UMKM di Kecamatan Punung Kabupaten Pacitan, Jawa Timur. Metode kegiatan dilakukan dengan beberapa tahap, antara lain:

1. Mengidentifikasi masalah yang terdapat dalam UMKM di Kecamatan Punung Kabupaten Pacitan.

2. Melakukan analisis situasi dengan cara observasi lapangan dan wawancara kepada pihak-pihak yang terkait.

3. Melakukan penilaian atas hasil analisis dan menetapkan program yang relevan.

4. Membuat storyboard dari poin-poin materi yang akan disampaikan.

5. Mengembangkan storyboard menjadi narasi agar dapat memandu saat penyampaian materi dan menyesuaikan batas minimal video.

6. Membuat video agar dapat menjadi bahan materi pembelajaran bagi UMKM.

\section{PELAKSANAAN DAN PEMBAHASAN}

Hal pertama yang dilakukan saat melaksanakan program ini adalah tahap observasi. Tahap ini dilakukan dengan mengamati dan memahami suatu fenomena yang ada untuk mendapatkan informasi tertentu dan melanjutkan sebuah penelitian. Observasi dilakukan pada dua tempat yaitu UMKM "Mukita" yang memproduksi olahan tempe berupa keripik, dan UMKM "Nyamleng" yang memproduksi berbagai olahan ketela. Hasil observasi menunjukkan bahwa pengetahuan dan minat akan pemasaran UMKM masih minim. Tahap observasi di UMKM Mukita dapat dilihat pada Gambar 1.

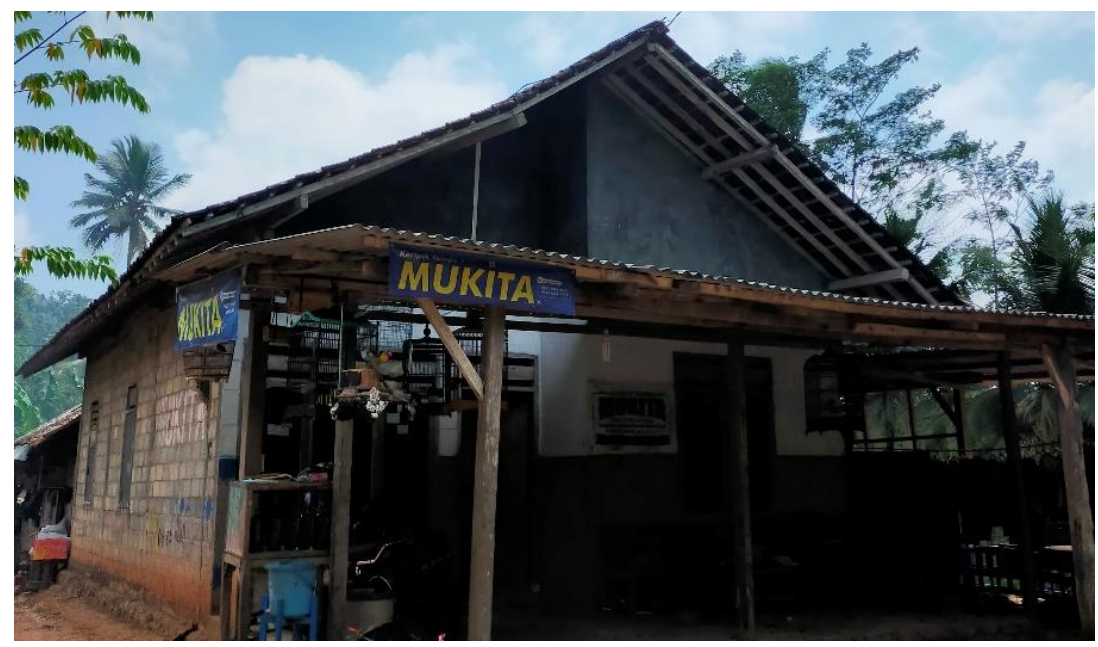

Gambar 1. Tahap observasi 
Setelah melakukan observasi, kemudian penulis menentukan topik kegiatan apa yang akan disampaikan kepada pemilik UMKM, dengan menyesuaikan permasalahan yang mereka hadapi dalam menjalankan usahanya. Dengan hasil observasi yaitu pemilik UMKM kesulitan dalam memasarkan produknya pada masa pandemi, kemudian dijadikan topik bahasan dan dikembangkan menjadi materi.

Selanjutnya, membuat storyboard dari poin-poin materi yang akan disampaikan. Storyboard dikembangkan menjadi narasi agar dapat memandu saat penyampaian materi dan menyesuaikan batas minimal video. Setelah menyiapkan materi berupa narasi dan storyboard, dilakukan pengambilan video untuk membuat video luaran. Pengambilan video dilakukan dengan terus mengacu pada narasi dan storyboard agar penjelasan materi tetap fokus dan tepat waktu sesuai dengan storyboard. Storyboard dapat dilihat pada Tabel 1.

Tabel 1. Storyboard

\begin{tabular}{|c|c|l|}
\hline No. & Durasi & \multicolumn{1}{|c|}{ Topik } \\
\hline 1 & $00.00-00.30$ & Perkenalan diri \\
\hline 2 & $00.31-02.00$ & Penjelasan pemasaran UMKM \\
\hline 3 & $02.01-03.00$ & Pengenalan green marketing \\
\hline 4 & $03.01-04.00$ & Penjelasan cara packing produk \\
\hline 5 & $04.01-05.00$ & Penjelasan cara packing produk dengan bahan ramah lingkungan \\
\hline
\end{tabular}

Selain menyiapkan storyboard, penulis juga membuat narasi untuk mengisi video. Narasi dibuat dalam Ms. Word dengan format tabel untuk memudahkan dalam proses perangkaian. Narasi tersebut dikembangkan dari topik dengan tiap-tiap durasi yang sudah ditetapkan. Gambar 2 menunjukkan proses dalam pembuatan narasi.

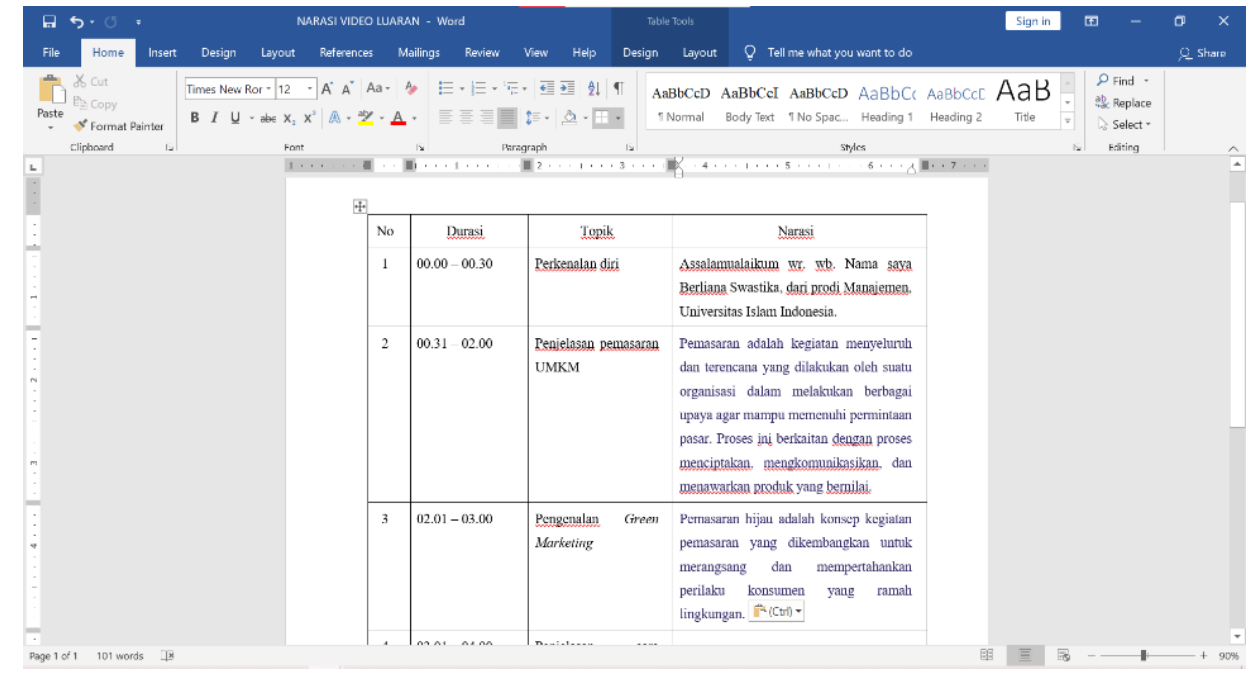

Gambar 2. Proses pembuatan narasi

Pengambilan video dilakukan di pabrik UMKM dan bertepatan dengan proses produksi, sehingga penulis dapat melihat langsung bagaimana bahan diolah hingga pengemasan. Tentunya pegawai UMKM sudah menjalani tes dan menjaga protokol kesehatan saat bekerja. 


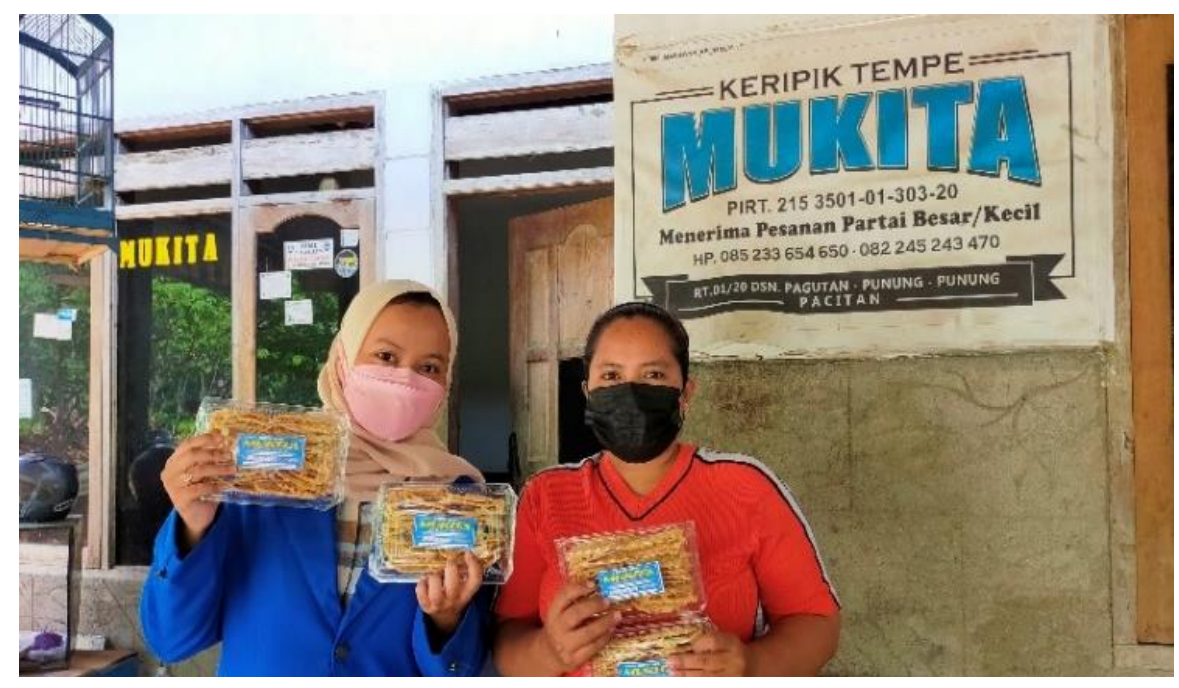

Gambar 3. Proses pengambilan video di UMKM "Mukita"

Video yang telah diambil kemudian diedit untuk menggabungkan tiap proses dan memadukan dengan latar belakang musik agar menarik secara visual maupun secara audio. Selain pengambilan video, juga dilakukan pengambilan rekaman suara untuk memasukkan narasi yang berisi materi dan informasi mengenai UMKM. Kemudian rekaman suara, latar belakang musik dan video digabungkan menjadi satu. Pengeditan dilakukan menggunakan gawai dan melalui aplikasi VN Video.

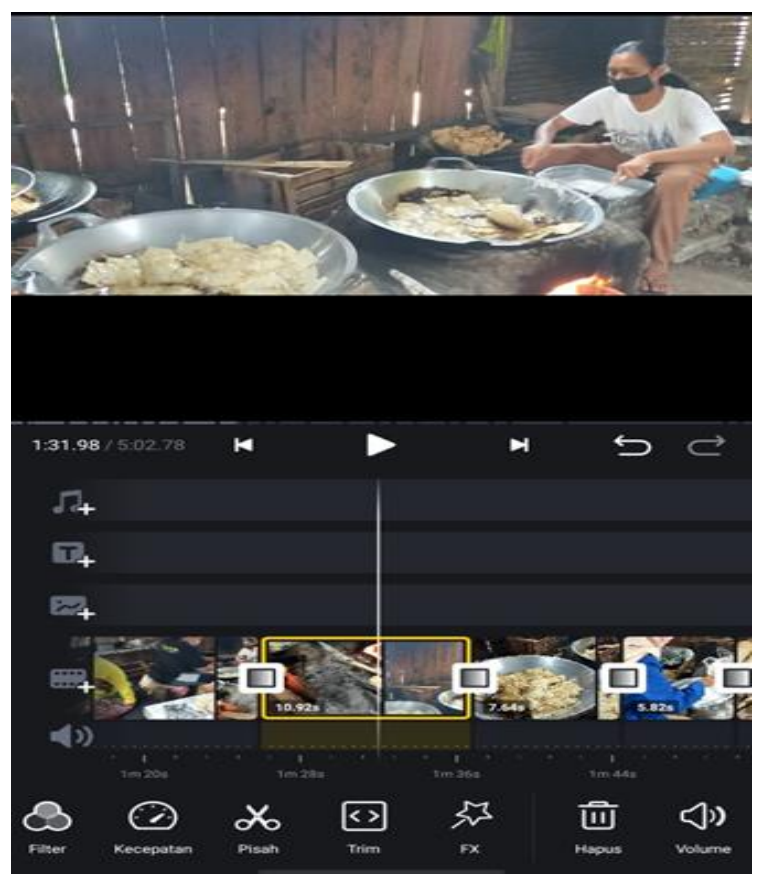

Gambar 4. Proses editing video luaran

Kemudian, video dari hasil kegiatan pengabdian yang telah dilakukan di Kecamatan Punung Kabupaten Pacitan dapat dilihat dengan pranala sementara: https://bit.ly/3t7pWPu. Tampilan layar video dapat dilihat pada Gambar 5. 


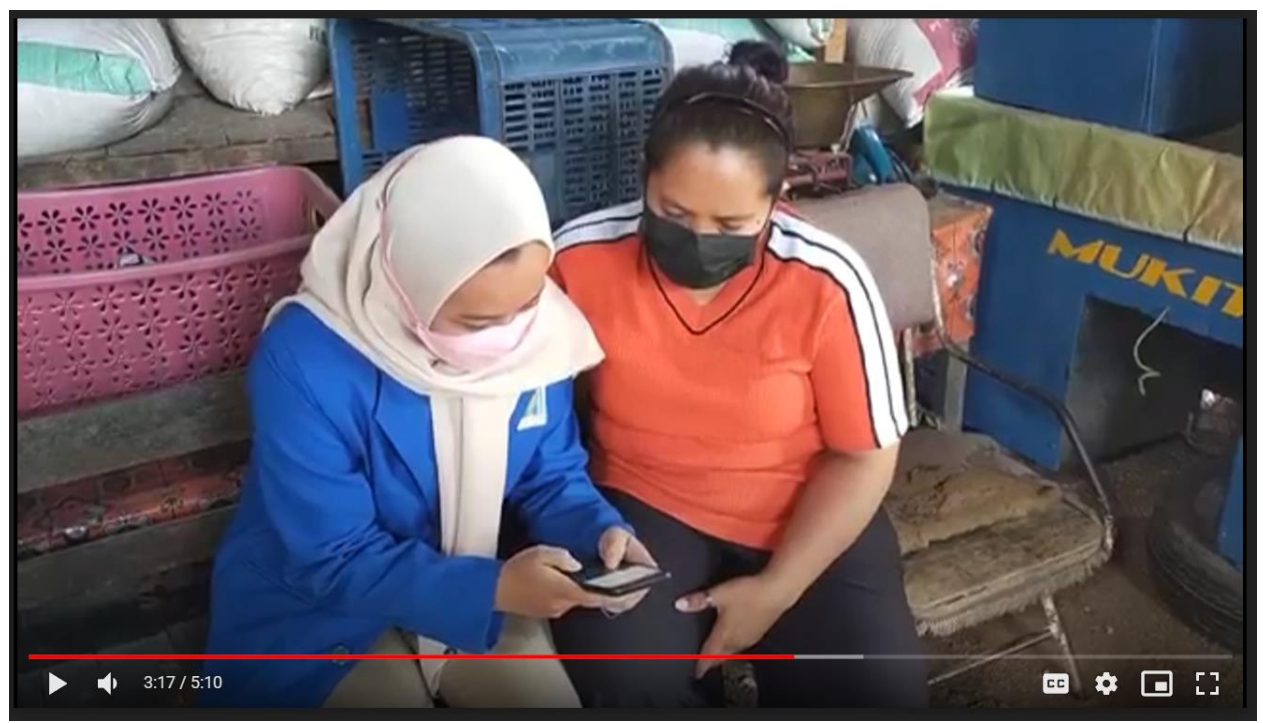

Gambar 5. Tampilan video

\section{SIMPULAN}

Kegiatan KKN PPM telah berjalan dengan lancar dan sukses. Pelaksanaan pemberdayaan masyarakat ini mendapat respon positif dari pelaku UMKM di Desa Punung karena berdampak pada peningkatan kapabilitas pelaku UMKM dalam memasarkan produk melalui sosial media maupun $e$ commerce. Di sisi lain, pemahaman mengenai green marketing dapat membantu dalam meningkatkan kesadaran para pelaku UMKM untuk menjaga lingkungan dalam proses produksi dan pemasaran produk mereka sebagai bentuk kelestarian lingkungan.

Program pengabdian yang dilakukan ini juga telah membangun manajemen organisasi yang lebih profesional dan akuntabel. Kegiatan pengabdian seperti ini sangat penting untuk dilaksanakan secara berkelanjutan dalam rangka meningkatkan bisnis UMKM di Indonesia menjadi lebih berkembang.

\section{UCAPAN TERIMA KASIH}

Penulis mengucapakan terima kasih kepada Direktorat Penelitian dan Pengabdian Masyarakat (DPPM) Universitas Islam Indonesia atas kerjasamanya sehingga kegiatan KKN ini dapat berjalan dengan baik.

\section{DAFTAR PUSTAKA}

'Aini, H. Q., \& Hapsari, A. Y. (2019). Interests Influence of Digital Marketing Product Sales in Exports by SMEs in Bandung. Global Business and Management Research, 11(1), 217-225.

Chaffey, D., \& Ellis-Chadwick, F. (2016). Digital Marketing: Strategy, Implementation and practice (6th ed.). Pearson.

Chen, Y. S., \& Chang, C. H. (2013). Towards green trust: The influences of green perceived quality, green perceived risk, and green satisfaction. Management Decision, 51(1), 63-82.

Hamdani, R., Hafiz, M. S., Marpaung, A. P., Dari, W., Darmawan, I. A., \& Rianto, H. (2021). Application of Knowledge Management as Strengthening the Maritime Sector in Indonesian SOEs. Proceedings of the 37th International Business Information Management Association 
JAMALI - Volume. 03, Issue. 02, September 2021

(IBIMA).

Marpaung, A. P., Hafiz, M. S., Koto, M., \& Dari, W. (2021). Strategi Peningkatan Kapasitas Usaha Pada Umkm Melalui Digital Marketing. Proceding Seminar Nasional Kewirausahaan, 2(1), 294 300.

Muhammad, R., Nurfauziya, A., \& Hamdani, R. (2021). Penerapan Sistem Informasi Kepegawaian Pada Amal Usaha Muhammadiyah Kota Magelang. Aksiologiya: Jurnal Pengabdian Kepada Masyarakat, 5(2), 147-153.

Setiawan, A., \& Hamdani, R. (2017). The Implementation of Crowdfunding-Based OVOB Program: An Improvement Effort of Global Competitiveness in Msme of Indonesia. The Proceeding of The International Conference and Call For Paper on Trade, 161-172. 